\title{
THE EFFECT OF REDUCED RATES OF CROP PROTECTION AGENTS AND ADJUVANTS ON PRODUCTIVITY, WEED INFESTATION AND HEALTH OF SPRING BARLEY (Hordeum sativum L.)
}

\author{
Cezary Andrzej Kwiatkowski, Marian Wesołowski, Elżbieta Harasim, \\ Dorota Gawęda, Magda Drabowicz
}

\author{
University of Life Sciences, Department of Herbology and Plant Cultivation Techniques \\ Akademicka 13, 20-950 Lublin, Poland \\ e-mail: czarkw@poczta.onet.pl
}

Received: 24.10 .2013

\section{Abstract}

A field experiment on the cultivation of spring barley was carried out in the period 2009-2011 at the Experimental Farm in Czesławice (central Lublin region) on grey-brown podzolic soil derived from loess (soil quality class II). The study included 3 rates of herbicides, growth retardant and fungicides $(100 \%, 75 \%$ and $50 \%)$ as well as different types of adjuvant (oil, surface-active, mineral). Plots without adjuvant were the control treatment.

A hypothesis was made that the reduction in rates of crop protection agents by $25-50 \%$, with the simultaneous addition of adjuvants, would allow spring barley productivity to be maintained at a level similar to that obtained under the conditions when recommended rates are applied without adjuvant. It was also assumed that particular types of adjuvant would show different interactions with specific groups of crop protection agents.

It has been proved that a rational reduction in rates of crop protection agents is up to a limit of $25 \%$, especially when an adjuvant is added to such reduced rates. This allows spring barley productivity to be maintained at the level obtained after the application of full rates (without adjuvant). But a further reduction in rates of crop protection agents by $50 \%$, in spite of the interaction of adjuvants, results in a significant deterioration of all spring barley yield components, since such conditions lead to increased occurrence of agricultural pests (weeds, fungal diseases) as well as increased crop lodging. Among the group of adjuvants tested in the present experiment, the oil adjuvant Atpolan 80 EC showed the best interaction with crop protection agents used.

Key words: spring barley (Hordeum sativum L.), adjuvants, reduced rates, yielding ability, yield components, agricultural pests

\section{INTRODUCTION}

Environmental protection considerations oblige both science and agricultural practice to address the issue related to decreased use of crop protection agents [1]. The reduction in rates of crop protection agents (CPAs) used entails the risk of lower crop productivity or worse yield quality as a result of increased occurrence of agricultural pests (weeds, fungal diseases, and crop pests) or adverse changes in the crop architecture, e.g. crop lodging [2]. The concept of reduced rates of crop protection agents is closely related to a change in the perception of the problem of control of agricultural pests. The purpose here is not to eliminate agricultural pests completely, but to reduce their occurrence to such a degree that they do not pose a threat to crops [3].

In recent years, agricultural practice uses more and more frequently adjuvants - biologically inactive substances that are aiding agents - in combination with crop protection agents. They lower the surface tension of the spray solution, improve the uniform coverage of the leaf surface, facilitate better uptake of pesticides by the plant and their penetration into it, and prevent crop protection sprays from being washed away by rain, and therefore they can compensate for a reduced dose of an active substance of CPAs [4, 5, 6].

Surface-active adjuvants (surfactants, oils and their derivatives as well as mineral adjuvants) used today should ensure optimal and more stable action of crop protection agents. Nevertheless, there are many mechanisms that can eliminate this role of adjuvants. Therefore, it is necessary to continue the research on adjuvants in the context of different weather and habitat 
conditions as well as different rates of CPAs in relation to specific crop plants, weeds, and other pathogens $[1,3,7]$.

In the present study, a hypothesis was made that the reduction in rates of crop protection agents by $25-50 \%$, with the simultaneous addition of adjuvants, would allow the yielding ability of spring barley to be maintained at a level similar to that determined under the conditions when recommended rates are applied without adjuvant. It was also assumed that particular adjuvants could show different interactions with the tested groups of crop protection agents.

The aim of the present study was to determine the effect of reduced rates of herbicides, fungicides and growth retardant as well as of three types of adjuvant on yield, crop components, weed infestation, health and lodging of spring barley.

\section{MATERIALS AND METHODS}

The field experiment on the cultivation of spring barley ('Justina') was carried out in the period 2009-2011 at the Czesławice Experimental Farm belonging to the University of Life Sciences in Lublin. It was set up as a split-block design with 3 replicates, in $27 \mathrm{~m}^{2}$ plots. The experiment was established on grey-brown podzolic soil derived from loess, classified as good wheat soil complex Sugar beet was the previous crop for spring barley in each year of the study (each year, the experiment was established in a different part of the field). Mineral fertilization, adjusted to high soil macronutrient availability, was applied at the following rates, calculated on a per hectare basis: $\mathrm{N}-60 \mathrm{~kg}$, $\mathrm{P}_{2} \mathrm{O}_{5}-50 \mathrm{~kg}, \mathrm{~K}_{2} \mathrm{O}-80 \mathrm{~kg}$.

The following factors were included in the study: Factor I.

Different rates used in comprehensive crop protection involving the combined application of herbicides, fungicides and growth regulators:

$100 \%$-application of herbicides, fungicides and growth regulators at rates recommended by the Institute of Plant Protection;

$75 \%$-rates of these agents reduced by $25 \%$ relative to recommended rates;

$50 \%$-rates reduced by $50 \%$ relative to recommended rates.

Factor II.

Type of adjuvant:

A - control treatment (without adjuvant);

B - Break Thru S 240 (surface-active adjuvant);

C - Atpolan 80 EC (oil adjuvant);

$\mathrm{D}$ - ammonium sulphate (mineral adjuvant).

The adjuvant Break Thru S 240 was applied at a rate of $0.91 \times$ ha $^{-1}$, Atpolan $80 \mathrm{EC}$ at a rate of $1.51 \times \mathrm{ha}^{-1}$, while ammonium sulphate ( $10 \%$ solution $)-1.51 \times$ ha $^{-1}$. The following crop protection agents were used: a mixture of the herbicides Chwastox Turbo 340 SL (a.i. MCPA + dicamba) + Puma Uniwersal 069 EW (fenoxaprop-P-ethyl + mefenpyr-diethyl $)-2.0+1.01 \times$ ha $^{-1}$ ( $100 \%$ rate), $1.5+0.751 \times$ ha $^{-1}$ (75\% rate), $1.0+0.51$ $\times$ ha $^{-1}(50 \%$ rate $)-$ in the spring at the tillering stage (BBCH 27-28); the growth retardant Cerone $480 \mathrm{SL}$ (ethephon) $-1.01 \times$ ha $^{-1}$ (100\% rate), $0.751 \times$ ha $^{-1}(75 \%$ rate), $0.5 \times 1 \mathrm{ha}^{-1}(50 \%$ rate $)$ - at the stem elongation stage (BBCH 31-32); the fungicides Tilt Plus 400 EC (propiconazole + fenpropidin) and Alert 375 SC (flusilazole + carbendazim) at identical rates $-1.01 \times$ ha $^{-1}$ (100\% rate), $0.751 \times$ ha $^{-1}$ (75\% rate), and $0.51 \times$ ha $^{-1}$ (50\% rate). The fungicide Alert $375 \mathrm{SC}$ was applied at the stem elongation stage (BBCH 31-32), whereas Tilt Plus $400 \mathrm{EC}$ at the stage $\mathrm{BBCH} 35-36$. The crop protection agents were applied using a field sprayer under a pressure of $0.25 \mathrm{MPa}$.

Number of ears of spring barley was determined on a $1 \mathrm{~m}^{2}$ area in each plot. Number of grains and grain weight per ear were determined on the basis of 30 randomly sampled ears from each plot.

Infection of barley plants by a complex of pathogens causing stem base diseases was determined at the milk stage (BBCH 75). 50 plants were pulled out from each plot. After washing away the soil, the plants were divided, depending on the degree of stem base infection, into groups using a 5-point graphic scale. Subsequently, the disease index for stem base diseases was calculated in accordance with Mc Kinney's formula given by $Ł$ a c i c o w a [8].

Evaluation of weed infestation of the spring barley crop was made twice; 4 weeks after herbicide treatment, weed damage was evaluated using a $1-9^{\circ}$ scale, whereas at the dough stage (BBCH 83-85) it was estimated using the dry-weight-rank method in test plots of $1 \times 0.5 \mathrm{~m}$, with two replicates per plot. Lodging of the spring barley crop was estimated several days before harvest using a $1-9^{\circ}$ scale.

Spring barley grain was harvested during the first 10-day period of August. The grain harvested from each plot was dried to bring it to the same moisture content (14\%), and subsequently grain yield was determined in $\mathrm{kg}$ and calculated on a per hectare basis.

The obtained results were statistically analysed by analysis of variance, while the significance of differences was determined by Tukey's test $(p=0.05)$.

The particular seasons during the study period differed in weather conditions. The year 2010 was the most favourable, as it was characterized by a mean annual air temperature of $8.5^{\circ} \mathrm{C}$ and total rainfall close to the long-term mean $-599.7 \mathrm{~mm}$. The year 2011 was wet and cold, since the total rainfall was $670.4 \mathrm{~mm}$, whereas the mean air temperature was only $7.4{ }^{\circ} \mathrm{C}$. 
The weather conditions in 2009 were average. In this year, the total rainfall was $618.3 \mathrm{~mm}$ and the mean air temperature was $7.9^{\circ} \mathrm{C}$.

\section{RESULTS}

Irrespective of the adjuvant, the 3-year average grain yield was significantly the lowest in the plots where rates of crop protection agents (CPAs) reduced by $1 / 2$ had been used; it was lower by about $15 \%$ relative to the treatments with recommended rates and by nearly $12 \%$ compared to the plots where CPA rates had been reduced by $1 / 4$. The reduction in rates of crop protection agents by half, with the simultaneous absence of adjuvant, resulted in obtaining the significantly lowest grain yield $\left(3.96 \mathrm{t} \times \mathrm{ha}^{-1}\right)$. The addition of adjuvants to the $50 \%$ rate of crop protection agents caused grain yield to increase to $4.45-4.66 \mathrm{t} \times \mathrm{ha}^{-1}$, reaching the level of grain yield obtained after the reduction of CPA rates by $25 \%$ and without the aid of adjuvants. The application of adjuvants together with lowering CPA rates by $1 / 4$ resulted in obtaining a comparable or even higher yield (Atpolan $80 \mathrm{EC}$ ) than that recorded when recommended rates had been applied $(100 \%)$ without adjuvant. Regardless of the herbicide rate, adjuvant application had an effect on increasing spring barley grain yield in the range of $0.27-0.52 \mathrm{t}$ $\times$ ha $^{-1}$. Statistically significant differences were found in the case of the adjuvants Atpolan $80 \mathrm{EC}$ and Break Thru S 240 (Table 1).

Irrespective of the type of adjuvant, the statistically proven highest grain yield of spring barley was harvested in the year 2010 which was characterized by the most favourable weather conditions (the highest mean air temperature and the lowest total rainfall) as well as by the lowest invasion of agricultural pests in the plantation (Table 2). What is important, in the above-mentioned year no statistically significant differences in spring barley grain yield were found between the treatments with $75 \%$ and $50 \%$ rates of CPAs. In the other growing seasons of spring barley, CPA rates reduced by $1 / 2$ caused a clear decrease in crop productivity compared to $100 \%$ and $75 \%$ rates. In the year 2011 which was abundant in rainfall, a statistically significant decline in spring barley grain yield was also found as a result of the reduction in CPA rates by $25 \%$ compared to the recommended rate. In the other years of the experiment (2009-2010), the differences in grain yield between the above-mentioned treatments were within the margin of experimental error (Table 2).

The application of recommended $(100 \%)$ rates of crop protection agents and rates reduced by $1 / 4$, irrespective of the adjuvant, resulted in similar density of ears per unit area in the spring barley crop (Table 3).It was only the reduction in CPA rates by $1 / 2$ that caused a significant decrease in the number of ears per $1 \mathrm{~m}^{2}$ compared to the treatments with the recommended rate, and the difference in ear density was about $9 \%$. The addition of adjuvants to the spray solution, irrespective of the CPA rate, contributed to an increase in the number of ears per unit area compared to control treatment A. However, a statistically significant increase in this trait (on average by 6\%) was found only in the case of the oil adjuvant Atpolan 80 EC. The statistically proven lowest number of ears per $1 \mathrm{~m}^{2}$ was found when rates of crop protection agents had been reduced by $1 / 2$ and no adjuvants had been added to the spray solution (Table 3).

The number of grains per ear of spring barley was the lowest in the treatments where only half of the rate of crop protection agents had been applied (Table 4), both in relation to the plots with the $100 \%$ rate of CPAs (on average by 11\%) and those with the $75 \%$ rate (on average by $7 \%$ ). All adjuvants included in the experiment contributed to a higher (by 0.8-1.8) number of grains per ear compared to this number found in the control plots. Statistically proven differences were found only in the case of the oil adjuvant Atpolan 80 EC and the surface-active adjuvant Break Thru S 240.

Among the experimental factors in question, only rates of crop protection agents contributed to significant differences in grain weight per ear of spring barley (Table 5). Irrespective of the type of adjuvant, the application of $100 \%$ and $75 \%$ rates of CPAs resulted in almost identical grain weight per ear. Among the adjuvants, only the oil adjuvant produced a more favourable trend towards an increase in this trait. The reduction in CPA rates by $50 \%$, in spite of the fact that the spray solution was supplemented with adjuvants, contributed to a significant decline in grain weight per ear, on average by $7 \%$ compared to the application of the other rates $(100 \%$ and $75 \%)$.

The application of recommended rates of crop protection agents maintained the stem base infection index of spring barley infected with a fungal disease complex at an average level of $9 \%$ (Table 6). Reducing rates of CPAs by $1 / 4$ and $1 / 2$ caused a significant increase in plant infection by about $14 \%$ and $31 \%$, respectively. The addition of adjuvants to the spray solution, compared to the control treatment, contributed to a significant decrease in the stem base infection index; the greater the reduction in the rate of the crop protection agent, the larger was the decrease. The statistically proven highest disease index of barley was found in the control treatment protected with CPA rates reduced by half.

The level of weed damage in the spring barley crop 4 weeks after the application of herbicides was significantly dependent on both experimental factors (Table 7). Irrespective of the adjuvant, the application of $100 \%$ and $75 \%$ rates of herbicides resulted in 
satisfactory elimination of weeds from the crop (the level of weed damage ranged 2.5-3.3). Reducing rates of herbicides by $50 \%$ caused a significantly lower level of weed damage compared to the treatments with recommended rates and rates reduced by L. Adjuvants proved to be an important aiding agent for herbicides in the elimination of weeds from the spring barley crop. Regardless of the herbicide rate, in all treatments where adjuvants had been used (B-D) weed damage was significantly larger compared to the control treatment (without adjuvant). The significantly lowest level of weed damage was found when rates of herbicides had been reduced by half and no adjuvant had been used.

The air-dry weight of weeds in the crop determined at the dough stage of spring barley was significantly the highest where CPA rates reduced by half had been applied (Table 8 ). In these treatments, the average dry weight of weeds was more than eight times higher relative to the other treatments. The reduction in the CPA rate by $50 \%$ and the absence of adjuvant resulted in significantly the greatest weed infestation. Irrespective of the CPA rate, the application of all three adjuvants contributed to a significant reduction in weed weight (on average by $25-40 \%$ ) compared to the control treatment.

Irrespective of the adjuvant, the application of recommended rates of crop protection agents and rates reduced by $25 \%$ did not cause significant differences in spring barley lodging (Table 9). Statistically proven higher crop lodging was recorded as a result of the reduction in CPA rates by $50 \%$. All adjuvants included in the study contributed to reduced lodging of spring barley, irrespective of the CPA rate. The application of the oil and mineral adjuvants guaranteed significantly reduced crop lodging (on average by $1.0-1.1$ percentage point) compared to the control treatment.

Regardless of the application of adjuvant or its absence, a significant negative correlation $(r=-0.62$;
-0.83) was found between increased weed infestation of the spring barley crop (air-dry weight of weeds) and grain yield in the treatment with rates of crop protection agents reduced by $50 \%$ (Table 10). Besides, dry weight of weeds was found to have a significantly negative effect on spring barley productivity in the treatment where rates of CPAs had been reduced by $25 \%$ and no adjuvant had been added to the spray solution.

Fungal diseases causing stem base damage were also found to have an adverse effect on spring barley productivity in the case where rates of crop protection agents had been reduced by $50 \%$ (Table 11). A particularly high negative correlation was observed when no adjuvant had been used (control treatment A). Only the oil adjuvant Atpolan 80 EC reduced the negative effect of stem base diseases (an insignificant correlation coefficient) on the yielding ability of spring barley. In the case of application of both $100 \%$ and $75 \%$ rates of crop protection agents, minimal crop lodging and in practice a marginal effect of this trait on spring barley yield were observed. A negative influence of crop lodging on barley productivity could be seen only in the treatment with rates of CPAs reduced by half (Table 12). Among the adjuvants considered, only Atpolan 80 EC beneficially affected the action of CPAs with rates reduced by $50 \%$.

An increased occurrence of agricultural pests as a result of reducing rates of crop protection agents by $50 \%\left(\mathrm{R}^{2}=0.88\right)$, and then by $25 \%\left(\mathrm{R}^{2}=0.80\right)$, had the greatest influence on spring barley yield. In the case of application of recommended rates $(100 \%)$, the value of the coefficient indicates a smaller effect of weeds, fungal diseases and in particular lodging on spring barley yield. Irrespective of the CPA rate, grain yield was most strongly determined by dry weight of weeds in the crop and then by stem base infection. The level of crop lodging was of lesser importance for yield (Table 13).

Table 1

Spring barley grain yield in $\mathrm{t} \times \mathrm{ha}^{-1}-$ mean for 2009-2011

\begin{tabular}{lcccc}
\hline \multirow{2}{*}{ Treatment } & \multicolumn{2}{c}{ Rates of crop protection agents } & Mean \\
\cline { 2 - 4 } & $100 \%$ & $75 \%$ & $50 \%$ & 4.59 \\
\hline A - Without adjuvant (control treatment) & 5.11 & 4.71 & 3.96 & 4.92 \\
B - Break Thru S 240 - surface-active adjuvant & 5.20 & 5.00 & 57 & 5.11 \\
C - Atpolan 80 EC - oil adjuvant & 5.38 & 5.29 & 4.66 & 4.86 \\
D - Ammonium sulphate & 5.16 & 4.97 & 4.41 & \\
Mean & 5.18 & 4.99 & & - \\
LSD (0.05) for: rates $=0.39$; adjuvants $=0.26$; interaction: rates x adjuvants $=0.43$ & & \\
\hline
\end{tabular}


Table 2

The effect of years and rates of crop protection agents on spring barley grain yield in $t \times \mathrm{ha}^{-1}$, irrespective of adjuvants

\begin{tabular}{ccccc}
\hline \multirow{2}{*}{ Year } & \multicolumn{3}{c}{ Rates of crop protection agents } & Mean \\
\cline { 2 - 4 } & $100 \%$ & $75 \%$ & $50 \%$ & 4.75 \\
2009 & 5.10 & 5.08 & 4.06 & 5.25 \\
2010 & 5.42 & 5.27 & 4.96 & 4.62 \\
LSD (0.05) for: years $=0.39$; interaction: rates x years $=0.40$ & 4.62 & 4.21 & \\
\hline
\end{tabular}

Table 3

Number of ears of spring barley per $1 \mathrm{~m}^{2}$ before harvest - mean for 2009-2011

\begin{tabular}{|c|c|c|c|c|}
\hline \multirow{2}{*}{ Treatment } & \multicolumn{3}{|c|}{ Rates of crop protection agents } & \multirow{2}{*}{ Mean } \\
\hline & $100 \%$ & $75 \%$ & $50 \%$ & \\
\hline A - Without adjuvant (control treatment) & 458 & 435 & 396 & 430 \\
\hline B - Break Thru S 240 - surface-active adjuvant & 466 & 453 & 428 & 449 \\
\hline $\mathrm{C}$ - Atpolan $80 \mathrm{EC}$ - oil adjuvant & 471 & 461 & 439 & 457 \\
\hline D - Ammonium sulphate & 462 & 452 & 429 & 448 \\
\hline Mean & 464 & 450 & 423 & - \\
\hline
\end{tabular}

Table 4

Number of grains per ear of spring barley [pcs.] - mean for 2009-2011

\begin{tabular}{lcccc}
\hline \multirow{2}{*}{ Treatment } & \multicolumn{2}{c}{ Rates of crop protection agents } & Mean \\
\cline { 2 - 4 } & $100 \%$ & $75 \%$ & $50 \%$ & 21.3 \\
\hline A - Without adjuvant (control treatment) & 22.3 & 21.6 & 20.0 & 21.6 \\
B - Break Thru S 240 - surface-active adjuvant & 24.0 & 22.8 & 21.9 & 23.1 \\
C - Atpolan 80 EC - oil adjuvant & 24.2 & 23.1 & 20.3 & 22.1 \\
D - Ammonium sulphate & 23.8 & 22.1 & 20.9 & - \\
Mean & 23.6 & 22.4 & & \\
LSD (0.05) for: rates $=1.5$; adjuvants $=1.4$; interaction: rates x adjuvants = n.s. & & & \\
\hline
\end{tabular}

Table 5

Grain weight per ear of spring barley [g] - mean for 2009-2011

\begin{tabular}{|c|c|c|c|c|}
\hline \multirow{2}{*}{ Treatment } & \multicolumn{3}{|c|}{ Rates of crop protection agents } & \multirow{2}{*}{ Mean } \\
\hline & $100 \%$ & $75 \%$ & $50 \%$ & \\
\hline A - Without adjuvant (control treatment) & 1.11 & 1.08 & 0.99 & 1.06 \\
\hline B - Break Thru S 240 - surface-active adjuvant & 1.12 & 1.11 & 1.07 & 1.10 \\
\hline $\mathrm{C}$ - Atpolan $80 \mathrm{EC}$ - oil adjuvant & 1.14 & 1.15 & 1.06 & 1.12 \\
\hline D -Ammonium sulphate & 1.12 & 1.10 & 1.03 & 1.08 \\
\hline Mean & 1.12 & 1.11 & 1.03 & - \\
\hline
\end{tabular}


Table 6

The stem base infection index of spring barley infected by a fungal disease complex (plants at the milk stage) - [\%] mean for 2009-2011

\begin{tabular}{lcccc}
\hline \multirow{2}{*}{ Treatment } & \multicolumn{2}{c}{ Rates of crop protection agents } & Mean \\
\cline { 2 - 4 } & $100 \%$ & $75 \%$ & $50 \%$ & \\
\hline A - Without adjuvant (control treatment) & 9.7 & 18.5 & 40.1 & 22.8 \\
B - Break Thru S 240 - surface-active adjuvant & 8.6 & 12.6 & 27.9 & 16.4 \\
C - Atpolan 80 EC - oil adjuvant & 7.8 & 10.7 & 21.3 & 13.3 \\
D - Ammonium sulphate & 9.0 & 13.0 & 33.6 & 18.5 \\
Mean & 8.8 & 13.7 & 30.7 & \\
LSD (0.05) for: rates = 2.4; adjuvants = 2.8; interaction: rates x adjuvants = 6.2 & & & \\
\hline
\end{tabular}

Table 7

The level of weed damage in the spring barley crop [on a 1-9 scale] 4 weeks after herbicide application - mean for 2009-2011

\begin{tabular}{|c|c|c|c|c|}
\hline \multirow{2}{*}{ Treatment } & \multicolumn{3}{|c|}{ Rates of crop protection agents } & \multirow{2}{*}{ Mean } \\
\hline & $100 \%$ & $75 \%$ & $50 \%$ & \\
\hline A - Without adjuvant (control treatment) & 2.9 & 3.7 & 6.3 & 4.3 \\
\hline B - Break Thru S 240 - surface-active adjuvant & 2.5 & 3.2 & 5.0 & 3.6 \\
\hline $\mathrm{C}$ - Atpolan $80 \mathrm{EC}$ - oil adjuvant & 2.2 & 3.0 & 4.8 & 3.3 \\
\hline D - Ammonium sulphate & 2.6 & 3.2 & 5.2 & 3.7 \\
\hline Mean & 2.5 & 3.3 & 5.3 & - \\
\hline
\end{tabular}

* 1 - complete destruction of weeds; 9 - no destruction of weeds

Table 8

Air-dry weight of weeds per $1 \mathrm{~m}^{2}$ in the spring barley crop [g] at the dough stage - mean for 2009-2011

\begin{tabular}{lcccc}
\hline \multirow{2}{*}{ Treatment } & \multicolumn{2}{c}{ Rates of crop protection agents } & Mean \\
\cline { 2 - 4 } & $100 \%$ & $75 \%$ & $50 \%$ & 21.1 \\
\hline A - Without adjuvant (control treatment) & 4.5 & 6.6 & 52.3 & \\
B - Break Thru S 240 - surface-active adjuvant & 4.0 & 5.6 & 32.4 & 14.0 \\
C - Atpolan 80 EC - oil adjuvant & 3.8 & 4.7 & 29.7 & 12.7 \\
D - Ammonium sulphate & 4.2 & 4.9 & 38.3 & 38.2 \\
Mean & 4.1 & 5.4 & & - \\
LSD (0.05) for: rates = 3.9; adjuvants = 4.4; interaction: rates x adjuvants = 12.9 & & & \\
\hline
\end{tabular}

Table 9

Spring barley lodging on a $1-9^{\circ}$ scale - mean for 2009-2011

\begin{tabular}{lcccc}
\hline \multirow{2}{*}{ Treatment } & \multicolumn{2}{c}{ Rates of crop protection agents } & Mean \\
\cline { 2 - 4 } & $100 \%$ & $75 \%$ & $50 \%$ & 6.8 \\
\hline A - Without adjuvant (control treatment) & 8.4 & 7.0 & 7.1 & 7.5 \\
B - Break Thru S 240 - surface-active adjuvant & 8.6 & 7.9 & 6.1 & 7.9 \\
C - Atpolan 80 EC - oil adjuvant & 9.0 & 8.3 & 6.4 & 7.8 \\
D - Ammonium sulphate & 9.0 & 8.1 & 6.0 & - \\
Mean & 8.7 & 7.8 & & \\
LSD (0.05) for: rates $=1.0$; adjuvants $=0.9$ & & & & \\
\hline
\end{tabular}

* 1 - complete lodging of the crop

9 - no lodging 
Table 10

Simple correlation coefficients (r) between air-dry weight of weeds and spring barley grain yield - mean for 2009-2011

\begin{tabular}{lccc}
\hline \multicolumn{1}{c}{ Treatment } & \multicolumn{3}{c}{ Rates of crop protection agents } \\
\cline { 2 - 4 } & $100 \%$ & $75 \%$ & $50 \%$ \\
\hline A - Without adjuvant (control treatment) & -0.21 & $-0.56^{*}$ & $-0.83^{*}$ \\
B - Break Thru S 240 - surface-active adjuvant & -0.09 & -0.36 & $-0.62^{*}$ \\
C - Atpolan 80 EC - oil adjuvant & -0.08 & -0.28 & $-0.64^{*}$ \\
D - Ammonium sulphate & -0.11 & -0.39 & $-0.77^{*}$ \\
${ }^{*}$ significant correlation coefficient (0.05) & & & \\
\hline
\end{tabular}

Table 11

Simple correlation coefficients (r) between the stem base infection index at the milk stage and spring barley grain yield - mean for 2009-2011

\begin{tabular}{lccc}
\hline \multicolumn{1}{c}{ Treatment } & \multicolumn{3}{c}{ Rates of crop protection agents } \\
\cline { 2 - 4 } & $100 \%$ & $75 \%$ & $50 \%$ \\
\hline A - Without adjuvant (control treatment) & -0.05 & -0.41 & $-0.71^{*}$ \\
B - Break Thru S 240 - surface-active adjuvant & 0.10 & -0.33 & $-0.57^{*}$ \\
C - Atpolan 80 EC - oil adjuvant & 0.07 & -0.29 & -0.49 \\
D - Ammonium sulphate & -0.03 & -0.30 & $-0.60^{*}$ \\
${ }^{*}$ significant correlation coefficient (0.05) & & & \\
\hline
\end{tabular}

Table 12

Simple correlation coefficients (r) between crop lodging and spring barley grain yield - mean for 2009-2011

\begin{tabular}{lccc}
\hline \multicolumn{1}{c}{ Treatment } & \multicolumn{3}{c}{ Rates of crop protection agents } \\
\cline { 2 - 4 } & $100 \%$ & $75 \%$ & $50 \%$ \\
\hline A - Without adjuvant (control treatment) & -0.06 & -0.26 & $-0.62^{*}$ \\
B - Break Thru S 240 - surface-active adjuvant & 0.01 & -0.11 & $-0.55^{*}$ \\
C - Atpolan 80 EC - oil adjuvant & 0.12 & -0.16 & -0.43 \\
D - Ammonium sulphate & -0.04 & -0.21 & $-0.59^{*}$ \\
$*$ significant correlation coefficient (0.05) & & & \\
\hline
\end{tabular}

Table 13

Coefficients of regression $(y)$ and determination $\left(\mathrm{R}^{2}\right)$ in a linear multiple regression equation for spring barley yield, depending on agricultural pests and crop lodging

\begin{tabular}{|c|c|c|c|c|c|c|}
\hline \multirow{2}{*}{ Regression equation } & \multirow{2}{*}{$\begin{array}{c}\text { Rates of crop } \\
\text { protection agents }\end{array}$} & \multirow{2}{*}{$\mathrm{R}^{2}$} & \multicolumn{4}{|c|}{ Coefficients } \\
\hline & & & ${ }^{1} b_{0}$ & $\mathrm{~b}_{1}$ & $\mathrm{~b}_{2}$ & $\mathrm{~b}_{3}$ \\
\hline \multirow{4}{*}{$y=b_{0}+b_{1} x_{1}+b_{2} x_{2}+b_{3} x_{3}$} & $100 \%$ & 0.69 & -3.219 & 3.227 & 0.516 & 0.133 \\
\hline & $75 \%$ & 0.80 & -3.278 & 4.105 & 0.781 & 0.145 \\
\hline & $50 \%$ & 0.88 & -3.428 & 4.592 & 1.004 & 0.306 \\
\hline & mean for rates & 0.79 & -3.308 & 3.974 & 0.767 & 0.194 \\
\hline
\end{tabular}

${ }^{1} b_{0}-$ the equation constant

$b_{1}$ - air-dry weight of weeds per $1 \mathrm{~m}^{2}$

$b_{2}$ - the stem base infection index at the milk stage

$b_{3}-$ spring barley crop lodging 


\section{DISCUSSION}

In the opinion of J a strzę b ska et al. [9] and Praczyk [3], the reduction in rates of crop protection agents applied involves the risk of a decrease in grain yield or deterioration of its quality as a result of lodging, increased weed infestation of the crop, or increased plant infection by fungal pathogens. Therefore, it is very important to determine the limit of reduction in CPA rates, after exceeding of which there is a dramatic decline in yield and the addition of adjuvants does not compensate for this trend [10]. The task of adjuvants is to support a stable effect of crop protection agents. But many factors (weather conditions, scope of reduction in CPA rates, type of crop) can affect the effectiveness of the interaction of adjuvants $[11,12]$.

A beneficial effect of adjuvant application has been found in particular in relation to the effectiveness of herbicides, and secondly, adjuvants have also been found to support fungicides and insecticides $[4,13,14$, 15]. There are few studies on reduced rates of retardants used in combination with adjuvant application. When applying retardants in winter wheat crops at maximum and minimum rates, Le s z c z y ń s k a and Grabiński [16] did not observe significant differences in crop lodging and crop productivity when they used the optimal time for application of this agent (the 2nd node stage).

The results of some studies prove that the reduction in rates of crop protection agents should not exceed $33 \%[17,18]$. The above opinion is confirmed by the results of the experiment in question. The reduction in rates of CPAs by $25 \%$ resulted in obtaining spring barley yield at a level similar to that obtained when full rates $(100 \%)$ were applied, whereas reducing these rates by $50 \%$ caused a noticeable decrease in yield. A rapid increase in weed infestation and an increased occurrence of fungal diseases damaging the stem base were the reason for that. In turn, P i e k a r c z y k [12] notes that in a well-cultured field with a low level of weed infestation, herbicide rates reduced by $25 \%$, and even $50 \%$ with the addition of adjuvants, are sufficient to control weed infestation of spring barley and to obtain yields at a level similar to treatments with rates recommended by the manufacturers of such agents. A similar opinion is presented by Ka pe lu s z n y [ $[19$, 20], but with the reservation that the optimal time of treatment (when weeds are at early growth stages) and proper weather conditions (the treatment should be carried out during evening hours with low wind) ensure the efficacy of weed control with the use of herbicide rates reduced by half.

According to some authors [17, 21], reduced rates of crop protection agents, which have a positive ecological effect, generally cause a decrease in yield due to the deterioration of most crop and yield components. The effectiveness of crop protection agents applied at reduced rates is lower in years in which there are lower air temperatures or excessive rainfall in the period when they are applied [22, 23].

\section{CONCLUSIONS}

1. It is possible to reduce rates of crop protection agents, aided by adjuvants, by $25 \%$ since it does not have a significant effect on weed infestation, health, crop lodging, or the deterioration of yield components of spring barley.

2. The reduction in rates of crop protection agents by $50 \%$ results in a clear deterioration of spring barley productivity, in particular under adverse weather conditions during the growing season, and the addition of adjuvants does not help to reduce this trend.

3. The supporting action of adjuvants increases as rates of crop protection agents are reduced. The type of adjuvant plays a smaller role for the effect on spring barley yield and its structure. The most supportive effect of pesticides was observed in the case of the oil adjuvant (Atpolan 80 EC).

4. The decreased productivity of spring barley protected with reduced rates of crop protection agents is primarily caused by increased weed competition and increased stem base infection by a fungal disease complex.

\section{Acknowledgements}

Research supported by the Ministry of Science and Higher Education of Poland as part of the statutory activities of the Department of Herbology and Plant Cultivation Techniques, University of Life Sciences in Lublin.

\section{Authors' contributions}

The following declarations about authors' contributions to the research have been made: concept of the study: CAK, MW; field work: EH, DG, MD; table arrangement: CAK, MW; writing the manuscript: CAK, EH.

\section{REFERENCES}

1. Woźnica Z. Współdziałanie adiuwantów a skuteczność chwastobójcza herbicydów. / Adjuvant interaction and efficacy of herbicides. Prog. Plant Protection / Post. Ochr. Rośl. 2003; 43 (1), 473-479. (in Polish)

2. Pawłowska J., Pecio A., Bichoński A. Wpływ różnych dawek herbicydów $\mathrm{z}$ dodatkiem adiuwanta na odchwaszczanie, plonowanie i wartość browarną jęczmienia jarego. / The influence of different herbicide doses with 
adjuvant on weed control, field and malting quality of spring barley. Post. Ochr. Rośl. 1999; 39 (2), 676-679. (in Polish)

3. Praczyk T. Rozwój badań i zastosowań adiuwantów w Polsce. / Progress in research and application of adjuvants in Poland. Post. Ochr. Rośl. 2001; 41 (1), 110-113. (in Polish)

4. Gaskin R.E., Murray R.J., Krishna H., Carpenter A. Effect of adjuvants on the retention of insecticide spray on cucumber and pea foliage. New Zeland Plant Protection, 2000; 53, 355-359.

5. Woźnica Z., Idziak R., Szewczyk R. Nowy, wielofunkcyjny adiuwant do herbicydów opartych na glifosacie. / A new, multifunctional adjuvant for herbicides based on glyphosate. Prog. Plant Protect. / Post. Ochr. Rośl. 2004; 44 (1), 531-537. (in Polish)

6. Kierzek R., Ratajkiewicz H. Wpływ adiuwantów i parametrów opryskiwania na retencję cieczy na liściach w wybranych roślinach jednoliściennych. / Effect of adjuvants and spray parameters on retention of liquids on selected monocotyledone foliage. Prog. Plant Protection/Post. Ochr. Roślin 2004; 44 (2), 828-831. (in Polish)

7. Holloway P.J., Bufler Ellis M.C., Webb D.A., Western N.M., Tuck S.R., Hayes A.L., Miller P.C.H. Effects of some agricultural tank-mix adjuvants on the deposition efficiency of aqueous sprays on foliage. Crop Protection, 2000; 19, 27-37. http://dx.doi. org/10.1016/S0261-2194(99)00079-4

8. Łacicowa B. Metoda szybkiej oceny odporności jęczmienia na Helminthosporium sativum P. K. et B. Biul. IHAR 1969; 3-4, 61-62. (in Polish)

9. Jastrzębska M., Brzozowski J., Kurowski T.P. Reakcja pszenicy ozimej na herbicydy stosowane łącznie $\mathrm{z}$ adiuwantem i mocznikiem. Cz. 1. Ocena uszkodzeń roślin i zdrowotność. / Winter response to herbicides applied with an adjuvant and urea. I. Evaluation of plant damage and health state. Biul. Nauk. UWM Olsztyn, 2001; 11, 115-125. (in Polish)

10. Kwiatkowski C., Wesołowski M., Juszczak J. Wpływ adiuwantów oraz zredukowanych dawek środków ochrony roślin na skład pokarmowy ziarna jęczmienia jarego. / Effect of adjuvants and reduced doses of pesticides on nutrient composition of spring barley grain. Acta Agrophys. 2011; 17 (2): 345-358. (in Polish)

11. Skrzypczak G., Pudełko J., Woźnica Z.Huzar 05 WG (jodosulfuron) i adiuwanty w uprawie pszenicy ozimej. / Huzar 05 WG (iodosulfuron) and adjuvants in winter wheat. Prog. Plant Protect. / Post. Ochr. Rośl. 2003; 44(2), 914-917. (in Polish)

12. Pi e k a r c z y k M. Możliwość redukcji dawek herbicydów Aminopielik Super 464 SL i Chisel 75 WG w odchwaszczaniu jęczmienia jarego / Potential of reduction of Aminopielik Super 464 SL and Chisel 75 WG herbicides for weed control in spring barley. Acta Sci. Pol. Agricultura 2005; 4(1), 89-95. (in Polish)
13. Adamczewski K., Praczyk T. Rape seed oil as herbicide adjuvant in Poland. Proc. $4^{\text {th }}$ Intern. Symp. 'Adjuvants for agrochemicals'. Melbourne, 1995; 374-378.

14. Błaszkowski J., Piech M. Comparison of seed-borne fungal communities of naked and husked oats and barley. Phytopatol. Pol. 2002; 24, 73-74.

15. Miziniak W. Biologiczna ocena retardantów w uprawie jęczmienia jarego. / Biological evaluation of retardants in spring barley. Prog. Plant Protect. / Post. Ochr. Rośl. 2004; 44(2), 962-965. (in Polish)

16. Leszczyńska D., Grabiński J. Efektywność retardantów w zasiewach pszenicy ozimej w zależności od dawki i terminu aplikacji. / Effectiveness of retardants in winter wheat depending on dose and application term. Prog. Plant Protect. / Post. Ochr. Rośl. 2003; 43 (2), 775-777. (in Polish)

17. Wesołowski M., Kwiatkowski C., Harasim E. Wpływ zmniejszonych dawek niektórych herbicydów na plonowanie i zachwaszczenie pszenicy ozimej / The influence of reduced dose of some herbicides on yielding and weed infestation of winter wheat. Prog. Plant Protect. / Post. Ochr. Rośl. 2005; 45 (2), 1194-1196. (in Polish)

18. Kwiatkowski C. Wpływ adiuwantów oraz zredukowanych dawek środków ochrony roślin na wskaźniki jakości technologicznej ziarna pszenicy ozimej. / Effect of adjuvants and reduced doses of pesticides on technological quality indices of winter wheat grain. Prog. Plant Protect. / Post. Ochr. Rośl. 2010; 50 (2), 994-998. (in Polish)

19. K a pelu s zny J. Zachwaszczenie łanu zbóż jarych w warunkach zróżnicowanej gęstości siewu i oszczędnego stosowania herbicydów. / Weed infestation of spring cereals in different density conditions and reduced herbicide doses. Prog. Plant Protect. / Post. Ochr. Rośl. 2002; 42 (2), 484486. (in Polish)

20. Kapeluszny J. Wpływ zróżnicowanej gęstości siewu i obniżonych dawek herbicydów na plonowanie zbóż jarych. / Effect of sowing densities and reduced herbicide doses on spring cereals yielding. Prog. Plant Protect. / Post. Ochr. Rośl. 2003; 43 (2), 718-721. (in Polish)

21. Kuś J. Dobra praktyka rolnicza w gospodarce płodozmianowej i uprawie roli. (w:) Dobre Praktyki w Produkcji Rolniczej. IUNG Puławy, 1998; 1: 279-300. (in Polish)

22. Matysiak K., Stachecki S. Skuteczność działania obniżonych dawek herbicydów w różnych warunkach pogodowych. / Weed control efficacy of reduced herbicide doses in spring wheat depending of weather conditions. J. Plant Protect. Res. 2003; 43 (4): 405-413. (in Polish)

23. Kieloch R. Wpływ adiuwantów na skuteczność tribenuronu metylu stosowanego w różnych warunkach temperatury i wilgotności względnej powietrza. / An influence of adjuvants on effectiveness of tribenuron-methyl applied in various temperature and relative humidity conditions. Prog. Plant Protect. / Post. Ochr. Rośl. 2006; 46 (2): 240-246. (in Polish) 


\section{Wpływ zredukowanych dawek środków ochrony roślin oraz adiuwantów na produkcyjność, zachwaszczenie i zdrowotność jęczmienia jarego (Hordeum sativum L.)}

\section{Streszczenie}

Doświadczenie polowe w uprawie jęczmienia jarego przeprowadzono w latach 2009-2011 w Gospodarstwie Doświadczalnym Czesławice (środkowa Lubelszczyzna) na glebie płowej wytworzonej z lessu (II klasa bonitacyjna). W badaniach uwzględniono 3 dawki herbicydów, antywylegacza i fungicydów $(100 \%, 75 \%, 50 \%)$ oraz rodzaj adiuwanta (olejowy, powierzchniowo-czynny, mineralny). Obiekt porównawczy stanowiły poletka bez adiuwanta.

Założono hipotezę, że obniżenie dawek środków ochrony roślin o $25-50 \%$ z jednoczesnym dodatkiem adiuwantów pozwoli na zapewnienie produkcyjności jęczmienia jarego na poziomie podobnym, do stwierdzonego w warunkach stosowania dawek zalecanych, bez adiuwanta. Przyjęto również, że poszczególne rodzaje adiuwanów wykazują zróżnicowane współdziałanie z konkretnymi grupami środków ochrony roślin.

Dowiedziono, iż racjonalna redukcja dawek środków ochrony roślin może sięgać granicy $25 \%$, zwłaszcza jeśli do obniżonych dawek dodamy adiuwanty. Zapewnia to produkcyjność jęczmienia jarego na poziomie uzyskanym po zastosowaniu dawek pełnych (bez adiuwanta). Natomiast dalsze ograniczanie dawek ŚOR o 50\%, pomimo współdziałania adiuwantów, skutkuje istotnym pogorszeniem wszystkich elementów struktury plonu jęczmienia jarego. W takich bowiem warunkach dochodzi do zwiększonego występowania agrofagów (chwasty, choroby grzybowe), a także nasilonego wylegania roślin. Spośród zastosowanych w doświadczeniu adiuwantów, najkorzystniejsze współdziałanie ze stosowanymi środkami ochrony roślin wykazywał adiuwant olejowy Atpolan 80 EC.

Handling Editor: Elżbieta Weryszko-Chmielewska

This is an Open Access digital version of the article distributed under the terms of the Creative Commons Attribution 3.0 License (creativecommons.org/licenses/by/3.0/), which permits redistribution, commercial and non-commercial, provided that the article is properly cited.

(C)The Author(s) 2013 Published by Polish Botanical Society 